\title{
THE DILEMMA OF WAR AND PEACE IN THE TREND OF THE XXI CENTURY (Russian - Ukrainian case)
}

The relevance of the research topic is determined by the search for ways to solve the dilemma of war and peace as a scientific problem in the context of the 21 st century trends. The dilemma of war and peace has always attracted the attention of philosophers, historians, political scientists, military strategists, and politicians. And this is quite natural, since they largely determine the fundamental interests of mankind related to its survival, existence and development. Thus, the dilemma of war and peace is a central issue of both national and international security. International security itself began to be referred to as a state of security of the peace from the threat of war between states, thereby the dilemma of war and peace acquires important political, philosophical, social and axiological significance.

The aim of the article is to analyze the dilemma of war and peace in terms of the theory of war and peace as one of the most pressing security issues in the theory of international relations. The subject of the study is the transformation of the dilemma of war and peace under the influence of 21 st century trends.

The objectives of the study are: improving the theory of war and peace in its modern interpretation in the new international environment; clarification of the essence and new content of the categories of war and peace and their interdependence; analysis of the impact of 21 st century trends on changing forms and relationships between war and peace; identification of relationships: interdependence and boundaries between hybrid warfare and hybrid peace; elucidation of criteria for determining the boundaries between the state of war and the state of peace and their hybrid nature in the context of modern international conflicts on the example of the Russian-Ukrainian war; analysis and forecast of the consequences of the unresolved dilemma of war and peace for the international security and national security of Ukraine in the context of 21 st century trends.

The research methodology is based on systemic, historical, structural, political and conflictologycal approaches to the study of the problem with the application of the theory of international relations, in particular, its neorealistic and neoliberal concepts. Research methods are comparative analysis, case study, observation, content analysis and prognostic methods.

The relevance of scientific issues related to the research of the dilemma of war and peace has existed at all times. Especially people were interested in this during the war and in the post-war period, when there was a need to preserve peace and ensure 
the safety of mankind from the emergence of a new war. However, wars emerged as constant companions of social, political, and international relations.

For example, Europe constantly lived in a state of war, since the multipolarity of the European architecture of inter-state relations was their constant source, which gave rise to two World wars. From 1945 until the last decade of the XX century, Europe lived in fear of a possible world nuclear warfare. It is obvious that this fear of mankind before the prospect of burning in a nuclear flame that made them appreciate the cold peace that has been established in the bipolar system of international relations.

A lifelong of democratic peace should have been reigned with the end of the Cold War. However, the post-bipolar world was also unstable and short-lived. The dilemma of war and peace in the XXI century has also not been resolved. The multipolar world has created new wars, the causes of which originated in a post-bipolar world. The essential feature of the dilemma of war and peace in the XXI century in comparison with the nuclear era was the blurring of the line between peace and war and the emergence of such a phenomenon as "hybrid peace" and "hybrid warfare."

The precondition for this situation was the main trends, which primarily include the transformation of the system of international relations to multipolarity, which led to an imbalance between the key players which maintained the existing order of the unipolar world led by the United States. Such a transformation led to cardinal geopolitical shifts and the emergence of statutory asymmetry between them. The change in the balance of power in this disrupted system has led to a revision of the balance of interests and spheres of influence.

The United States' gradual loss of its global leadership has led to a revision of the World order. New contenders for regional dominance have emerged, trying to fill the vacuum of regional influence and security. Such an imbalance in power could be overcome by a hybrid war in which this imbalance loses its significance due to the shift of the battlefield into the information, social and cognitive spheres, which blurs the traditional notion of peace and war.

The second trend of changing the modality of peace and war is the emergence of a global information space, the formation of social networks and network society. Thus, modern historical development marks a transition from the industrial to the information age, when the main way of life of mankind is the production of information products. Hence, the main weapon, along with physical, conventional or nuclear weapons, is information one. The emergence of such a global space transfers war into the cognitive sphere and leads to an increase in its spatial scale without a direct military invasion and a clear framework for the beginning and end of the war. "In the 21st century," of the Army General Valery Gerasimov, Chief of the General Staff of the RF Armed Forces, asserted, "there is a tendency towards the elimination of the differences between the states of war and peace. Wars are now not even declared but, having begun, are not going according to a pattern we are accustomed to" (Gerasimov, 2013).

The third trend that causes this phenomenon of blurring is due to increased opportunities for coercion by non-military means, the so-called "soft power," which is comparable in effectiveness to military means. The study of the role of soft power in interstate relations is mainly the focus of works of the neoliberal school representatives. However, little attention was paid to the use of soft power in the war. In new concepts 
of war, soft power is typical for peacetime, but in war it is used as a weapon, which is also one of the factors in blurring the boundaries between war and peace and interpenetration into each other. Russian Army General M. Gareev wrote in this regard: "The fact is that some non-military means of combat have received unprecedented technical development, acquired a very powerful and strong character. For example, targeted cyber-attacks, which can be carried out by both government intelligence and individuals, can cause serious complications in the energy, banking and financial systems of opposing countries. And all this is done in secret, and it is not always possible to establish where the cyber-attacks came from, and therefore it will be unclear what country to declare a war on. In general, if all these actions are considered a declaration of war, then there may be a situation of constant war of all against all" (Gareev, 2013). Thus, such a hybrid of war and peace may have no indications of an armed struggle, but it leads to the same results as traditional war.

The process of globalization has led to reversible trends, such as: regionalization and inter-civilizational structuring of the new world order, which can be considered the fourth important prerequisite for changing the modality of war and peace. The formation of large inter-civilizational communities in the 21 st century makes them the main subjects of inter-civilizational conflicts, as S. Huntington wrote. The main object of such conflicts is intangible values. The hybrid war is a struggle for values, the destruction of the opponent's values and the imposition of your own values. Since such a struggle is waged by both military and peaceful means, it leads to an increase in the diffusion of these states of war and peace (Dickinson, 2021). Culture, religion, identity become both objects and means of warfare. The second aspect of this trend in the context of the problem chosen for consideration is that civilizations are perhaps the largest clusters of world order, the destruction and capture of which are considered as a way to establish regional and global dominance.

The need to change the modality of war and peace arose at the end of the 20th century, when mankind realized the enormous destructive power of modern weapons and the fatal consequences of nuclear war for humanity and the natural environment itself. Therefore, for example, the advantage of hybrid war is that it makes it possible to avoid such catastrophic consequences in comparison with nuclear or large-scale conventional wars and at the same time to preserve its political essence as "the continuation of politics by other means," according to the Clausewitz formula, which has become the trend of the 21 st century.

The analysis of these trends led to the author's hypothesis of the study. It is that in the 21 st century, under the influence of trends of a multipolar world, the boundaries between war and peace are blurred by interpenetration, convergence, combining goals and means of both peacetime and wartime, mixing both military and non-military aspects, which change the modality of both war and peace. Such erosion creates a situation of global chaos, which will lead to the loss of the status hierarchy of international relations system and existing structures of both national and international security.

The author believes that in the presence of such a process, in the future, existing systems and security structures will not be able to respond to the threat of war and other military threats to national and international security. This combination of war and peace creates chaos and anarchy in international relations, when, for example, the 
Russian-Ukrainian war, that arose in the Donbas on the territory of Ukraine can be simultaneously classified as a "Ukrainian crisis," "internal conflict," local war, regional war, global conflict, and also qualified as a "hybrid peace" in all these dimensions. In such a situation, war and peace lose their parameters and manifestations, when the war in Syria can affect Europe in the form of refugees and illegal migrants. Thus, Europe, unwittingly, forced to take on the burden of the Syrian war, which gives Russia a great chance to manipulate internal processes in Europe itself, destroying the EU and NATO states on the inside. These new circumstances have made the study of the dilemma of war and peace an important object in the theory of international relations.

\section{WAR AND PEACE AS CATEGORIES THEORY OF INTERNATIONAL RELATIONS}

As a philosophical category, dilemma is a polemical evidence with two opposite propositions that exclude each other and do not allow for a possible third judgment. In a broad interpretation, dilemma is considered as a complicated situation of choosing between two unacceptable possibilities (Filosofckiy eyciklopedicheskiy slovar, 1983: 166).

With this definition, the dilemma of war and peace is denoted by the dichotomy of these two categories, when "peace" is qualified as "not war," i.e. the absence of war, and the state of war as "not peace," i.e. the absence of peace. This dichotomy defines the essence of the dilemma of war and peace in their dialectical contrasts, contradictions, and interconnectedness.

Since peace and war are interdependent categories, then the question arises where is the watershed that separates war from peace, and peace from war? Where are the criteria by which we can clearly determine what is the peace or war? Various theories explain this.

The results of many studies of war and peace became such a scientific direction as the theory of war and peace (Theories of war and peace, 2001; Conflict in World Politics, 1998; Nations at War, 1998). The greatest contribution to the development of this theory was made by representatives of the school of political realism, neorealism and neoliberalism (Nations at War, 1998: 12-30).

The theory of political realism and neorealism consider war as a certain state of relations between states, which are determined by their power balance. According to this criterion, war is interpreted as a struggle for power or for the advantage in power. It is the balance of power that forms the structure of international relations from the point of view of neorealism. The appeal to force is justified by the fact that anarchy reigns in international relations, since states in the international arena pursue their own national interests and do not consider the interests of others.

In principle, neorealists argue that states make decisions in favour of war and peace depending on the balance of power and its changes in the structure of the system of international relations. Thus, John Mearsheimer, a proponent of Kenneth Waltz's structural realism, analysed the structuring of power in international relations during the 1990s. In the famous article "Back to the Future: Instability in Europe 
after the Cold War," he predicted the pessimistic future of Europe (Mearsheimer, 2001: 3-54).

Such a pessimistic conclusion John Mearsheimer justifies that Europe has had a stable peace for 45 years thanks to the two key factors: a bipolar system that was peaceful thanks to the deterrent effect of nuclear weapons. If the Soviet Union and the United States leave Europe, he is sure that Europe will move to multipolarity and then there will be an era of wars and systemic crises that will break the continent. According to the arguments of Mearsheimer, states start a war, being convinced that war gives more advantages and achievements than risks and losses that arise in this case (Ibid.: 4-8).

These achievements and losses depend on two factors: the balance of power between states and the nature and properties of military power. The first factor includes the number of superpowers in the system of international relations, depending on which systems can be bipolar or multipolar. The second factor is determined by the destructive property of military force, provided that the offensive weapons has an advantage over the defensive. Mearsheimer argues that nuclear weapons give defense more advantages, but he believes that convection offensive forces and defense advantages cannot be commensurate and inappropriate (Ibid.: 11-18).

According Mearsheimer 's argument, wars in a bipolar system are less likely than in a multipolar system. In a bipolar system where there are only two superpowers, the number of potential conflicts is much lower because only two superpowers can take part in a global war. It is also much easier to contain aggression in a bipolar system because the two superpowers do not depend on the uncertainty of forming other alliances and can restrain each other. All these factors that strengthen peace are absent in the multidimensional world. That is why Mearsheimer argues that nuclear weapons are the pledge of peace, unlike a multipolar world where there are no peacekeeping factors (Ibid.: 20-27).

Based on these explanations, "power" and "national interest" are the central categories of classical realism and neorealism. Thus, war from the point of view of these theories can be defined as relations between states with the use of force, and peace is a relationship where states figuring things out without the use of power potential. Although the struggle for such peace, according to the proponents of these theories, should also be achieved with the use of force. This is reflected in the ancient proverb: "if you want peace, prepare for war." In international relations, the activity of states based on the principles of non-use of force or threat of force is called the policy of peaceful coexistence.

Thus, war, like peace, is a state of international relations. This is actually the feature that most unites them. The only difference between them is that war is such a state in the conditions of the greatest tension of confrontation between states and the highest aggravation of their antagonistic interests, peace, on the contrary, is characterized by the absence of such signs in relations between states.

We find a different view of the role of force in international relations and the category of "peace" in the neoliberal approaches presented, in particular, in the theory of democratic peace. Representatives of the neoliberal school pay more attention to the research of the "peace" category. According to the theory of democratic peace, states with democratic regimes always prefer peace over war. The causes of wars 
unleashed by democratic countries can only be when they are aimed at achieving peace and freedom. For example, John Owen in his publication "How liberalism produces a democratic peace" shows how liberal principles and the democratic process, embodied together, make war between democracies almost impossible (Owen, 2001: 137-147).

John Owen considers those states with liberal democracy "where liberalism is the dominant ideology, where citizens have control over decision-making regarding war." It is precisely because liberal states have liberal institutional structures, foreign policy is under public control and non-liberal leaders do not have the ability to engage liberal states in war against other liberal states (Ibid.: 149-174).

In particular this theory focuses on the dependence of war or peace on the nature and type of existing regimes (Owen, 2001: 184). States with democratic regimes do not tend to fight each other, while authoritarian and totalitarian regimes prefer wars to achieve their goals and interests. It must therefore be concluded that in order to strengthen the state of peace in the world, it is necessary to establish democratic regimes in states.

The second important postulate of neoliberal theory is reduced to a structural understanding of the nature of power, where traditional military force is not considered dominant, because in the global world, states are becoming more interdependent, and therefore the victory in the war does not have the same value as the neorealists claim (Copeland, 2001: 468). More important is the price of this victory and the cost of the war itself. Therefore, in these conditions, the so-called "soft power" is more attractive in comparison with "hard power," which includes economic, diplomatic, energy, financial, humanitarian and other components (Nye, 2004).

Other neoliberal aspects of the theory of war and peace include: discussions on how international institutions can contribute to the consolidation of peace (Hopmann, 2000: 569-615; Zaemskiy, 2008; Lewis, Marks, 1998) and how increasing economic interdependence and pressure on environment will affect the future of peace and war (Copeland, 2001: 464-500; Homer-Dixon, 2001: 501-535).

But, in this case, the question: arises again how to distinguish "war" from "peace," since these means of soft power are widely used in peacetime, both in foreign and domestic policy of states. In this case, war is traditionally defined by the presence of not just hard power, but armed struggle as a bilateral process of using armed force. The traditional this definition formulated as "organized armed struggle between states (group of states), classes, or nations (peoples)" (Filosofckiy eyciklopedicheskiy slovar, 1983: 166).

Therefore, if we take this criterion of armed struggle as the basis for defining war and peace, then "war" is characterized by the presence of armed struggle between its subjects, and "peace" is characterized by its absence. Instead, in many countries' doctrinal and conceptual documents, armed struggle is defined by the term "armed conflict," which is removed from the concept of "war" and is rather considered an intermediate state between war and peace, that is, a separate form of interaction not between states, but between their armed forces. Thus, the Military Doctrine of Ukraine, provides this definition of the term "armed conflict." "An armed conflict is an armed conflict between two states (an international armed conflict is an armed conflict on the 
state border), or between warring parties within one state, usually at the expense of external support (an internal armed conflict)" (Woenna doktrina Ukraine, 2015).

Certain works are devoted to the researches of the role of individual instruments in the outbreak of war or in establishing peace. For example, one of the researchers in this field, Michael Herman, in his book "Intelligence power in peace and war," presented his comprehensive analysis of the role of intelligence services in war and in the peacekeeping process (Herman,1996). An attempt to carry out a comprehensive analysis of war and peace, which would include their negative and positive aspects, conceptual, moral, psychological, military, political, esoteric and historical aspects of these phenomena are described in the book by Sergey Mosov: "Peace or War: Can humanity make the choice?" (Mosov, 2007).

Historical science also pays great attention to the issue of war and peace, in particular the place of war and peace in the history of international relations. Kalevi Holsti's book "Peace and War: Armed Conflicts and International Order, 1648-1989" is also devoted to this historical theme, in which he describes the place of the problem of war and peace in various systems of international relations, in various historical epochs, as well as the role, played by the wars in the construction of national states, changing their territory, in ideology, religion, economy, and humanitarian understanding (Holsti, 1998). The history of bilateral Ukrainian-Polish relations in the categories of war and peace is described in the book "Wars and peace, or Ukrainians-Poles: brothers/ enemies, neighbors," edited by Ivshina L. (Wojni i mir, 2012).

Beyond these different scientific approaches, after the end of the Second World War, there was a need for a deeper rethinking of the very phenomenon of war and its consequences for humanity. Thus, a separate specialized system of knowledge, which was called "polemology" arose, i.e. the science that studies war, armed conflict and armed violence. Somewhat later in the 1970s and 1980s, when mankind realized the catastrophic consequences of a possible nuclear war and the emergence of the Pugwash movement, scientists in various fields of science became interested in studying the phenomenon of peace, which is closely linked to war and is a certain alternative to it. The result of their research was the "Irenology" studies as a scientific theory of peace.

However, for both polemology and irenology, the problem of defining the subject area of these sciences remained unresolved, as war and peace and conflict have already been studied by different sciences. It turned out that both polemology and irenology are interdisciplinary sciences. Philosophical knowledge became the basis for political science, beginning with treatises on war in ancient Greek philosophy and ending with modern philosophical theories. In this context, the scientific article of the Polish researcher Ryczard Rosa "The problem of war in a philosophical perspective" attracts attention (Rosa, 2018: 32-39). Trying to outline a philosophical perspective, he suggests that it is philosophy that can play a significant role in the interstate discourse on the phenomenon of war, as well as on the current state of future research on military security.

Ryczard Rosa justifies the development of polemology in the bosom of philosophy by the fact that, unlike many sciences, from the very beginning of its existence, philosophy has holistically interpreted these issues in connection with the world of nature 
and culture in the broad context of ontological, epistemological, axiological and praxeological reasoning (Rosa, 2018: 32). On the grounds of such a philosophical basis, the author proposes to combine knowledge about peace, war and security as philosophical categories under one name "Philosophy of Security." In his opinion, such a branch of knowledge can serve to build general security theories (Rosa, 2018: 32).

It is worth noting that a whole galaxy of scientists has grown up in Poland, who have made quite thorough progress in the study of this topic, forming a national polemological school. Such numerous co-founders of this school include: Ryczard Rosa, Krzysztof Drabik, Janusz Świnjarski, Mariusz Kubiak, Robert Ptaszek, Tadeusz Szurek, Roman Leszek, Jacek Reginia-Zacharski, J. Borgosz and others. In Ukraine, Doctor of philosophical sciences, Professor O. A. Bazaluk dedicated his works to this topic of philosophy of war and peace. (Bazaluk, 2016). Another point of view is presented by Western European and Russian researchers. They argue that polemology is one of the areas of sociology, which deals with the study of war, armed conflict, military violence and collective aggression (Solovyov, 2002).

The vast majority of polemological works are devoted to the history of the formation of knowledge about the war. Some publications consider the essence of war. In particular, Janusz Ignacy Symonides defines war as an armed struggle directed against the enemy. War is intended to help resolve disputes through violence (Symonides, 1983: 42). Jerzy Wiatr describes war as an external or internal conflict that is resolved only through violence (Wiatr, 1964: 50).

During these times, polemology has developed its own methodology for studying war on the basis of such methods as comparative, structural and statistical analysis. Particular attention is paid to the factors that cause the frequency of wars and military conflicts, determining the indicators of their intensity. According to this polemological approach, given the criteria of the method of warfare, there are 4 generations. The first generation includes wars of pre-industrial age. The wars of the second generation differed from the first by large armies and the size of the theater of operations. The main feature of the wars of the third generation was their high maneuverability and firepower. The wars of the fourth generation include modern hybrid warfare, which is the subject of this article. Representatives of polemology note such features as multidimensionality and going beyond the territory of a multi-level complex of military and non-military actions aimed at the simultaneous achievement of various goals, which fundamentally distinguishes it from the wars of previous generations (Banasik, Parafianowicz, 2015: 7).

As for the relationship between war and peace, in support of the author's hypothesis, we should refer to the article by Roman Lucas, in which he points to the interpenetration of these phenomena, and hence to the inextricable connection between polemology and irenology. But at the same time, he also highlights the differences in the functions of these disciplines "Polemologists, in order to build peace, try to eliminate the phenomenon of war, while irenologists want to build peace by studying its theory. However, the difference lies in the fact that polemology begins with familiarization with the causes of war and aims to eliminate them, and by eliminating them - to create peace, while irenology seeks to eliminate war, building peace by eliminating war" (Łukasz Roman, 2017: 85). 
In its main directions and structure, research in the field of irenology is similar to polemological research. They explore the history of the development of knowledge about the peace, factors that can eliminate war and ways of establishing peace, which exclude the very possibility of a policy with the use of force. This problem is especially relevant for the settlement of the Russian-Ukrainian conflict in the Donbas. This issue is reflected in many publications of such authors as: R. Dodonov (Dodonov, 2015: 107-112), I. Dulebova, H. Kovalskiy, V. Dodonova, V. Biletsky (Dulebova, Kovalskiy, Dodonova, Biletsky, 2018: 59-65), V. Horbulin (Horbulin, 2017) where an attempt to philosophically rethink the theories of war and peace is presented and information tools for establishing peace in the east of Ukraine are proposed.

The Philosophical and Ontological Understanding of the Dilemma of War and Peace is described in the book B. O. Parahonskiy and G. M. Yavorska "Ontology of War and Peace." In this book, the essence of war and peace is revealed through a strategic and security paradigm with the inclusion of multilevel interaction of cognitive meanings. The authors assume the connection of ontological models with modern methods of warfare, in particular the connection of hybrid warfare with the logic of postmodern relativism and the general struggle with the power order (Parahonskiy, Yavorska, 2019).

Other important problems the dilemma war and peace of this conflicting scientific direction should include investigation of the culture of war and the culture of peace, security of the peace, forecasting conflict-generating factors inherent in the XXI century, the analysis of the dynamics of the Eurasian conflicts, the transcendental approach in the research practices of the peace. In particular, Carl Jacobsen in the book "In search of peace: The way to overcome" considers the problem of overcoming war and finding a way to peace through such a concept as "culture," interpreting this problem in the formula "War Culture vs Peace Culture." The author researches the defining parameters of the culture of war, their meaning and consequences for peace and security (Jacobsen, 2000: 3-48). Obviously, this monograph is about the culture of war and the culture of peace, as a certain part of the content of strategic culture.

Over the past 30 years, research of a conflictological nature, the object of which is the category of "conflict," the multilateral aspects of the causes of international conflicts and the problems of their settlement, and related peacekeeping activities has become a separate scientific field. Among these problems: the research of the evolution of conflicts, international crises and wars, foreign policy relations and international conflicts (Pfersch, Rohloff, 2000; The History and Future of Warfare, 1999). In the context of the transformation of international relations from a monopolar to a multipolar system, researches of asymmetric conflicts and the nature of asymmetric wars have become relevant (Leech, 2002; Paul,1994).

However, among the specified conflict-generating field, the most common are researches on strategies for resolving international conflicts (International conflict resolution, 2000; Lewis, Marks, 1998), as well as certain aspects of peacekeeping such as multilateral and unilateral external interventions in the settlement of internal conflicts and civil wars (Regan, 2000). Applied aspects of conflict resolution research relate to different stages of peacekeeping activities and include such areas as: conflict prevention (Ackermann, 1999), peace enforcement (Boulden, 2001), peacekeeping, peacebuilding and reconciliation (Long, Brecke, 2003). 
Thus, the research of such categories as "war," "peace," and "conflict" resulted in three scientific directions, which are presented in the theory of peace, the theory of war, the theory of conflict resolution and peacekeeping. Thus, the ratio of the categories "war," "peace" and "conflict" are interdependent (Conflict in World Politics, 1998). Conflict can also exist if there is peace at the stage of its latent development, when there is no use of military force between the conflicting parties. This state is called a "cold peace," a confrontation relation or an international crisis.

Obviously, this interdependence has led to the fact that in the Military Doctrine of Ukraine armed conflict next to war is considered to be two main types of "military conflict," which in turn is "a form of resolving interstate or internal conflicts with the bilateral use of military force" (Woenna doktrina Ukraine, 2015). As follows from the content of this definition, a military conflict is understood as a war. Because it contains not only purely military, but also political signs of war. But there is no separate definition of the term "war." Apparently, the creators and legislators of this document deliberately avoided the term "war" for political reasons, so as not to recognize the real state of the war between Ukraine and Russia. Such a substitution of concepts led to a blurring of the very understanding of war and the strategy of the state's actions in conditions of war, and thus the organization defence of the state.

In the Russian military doctrine approved by the Decree of the President of the Russian Federation Vladimir Putin on December 25, 2014 we observe the same classification of military conflicts where the political essence of war is revealed only in definition of its local, regional and large-scale form (Woennay doktrina Rossiyckoy Federacii, 2014). Although the criterion for such a definition of the forms of military conflict is not the very political essence of the war, but the scale of the military-political goals pursued in it. The similarity of the wording in the Russian and Ukrainian military doctrines stems from the common Soviet strategic culture of the creators of these documents. Moreover, the Military Doctrine of Ukraine was approved 9 months later than the Russian military doctrine. Thus, the Russian military doctrine was taken as a model in the creation of the Military Doctrine of Ukraine.

The only difference between these doctrines is that classification of military conflicts in the military doctrine of the Russian Federation indicates a large-scale war between the largest states of the world community. Russia regards itself as a "world state" and obviously is going to participate in such wars. There is no such definition in Ukrainian military doctrine. It is indicated only that war is a type of "military conflict," and can be both local and regional in scope. Russia's Military Doctrine also clarifies "military conflict" as a generalizing category that covers all types of armed conflict, in contrast to the Ukrainian version.

At the same time, peace in the categories of war is the result of either victory or defeat in it. And this is the shortest way to achieve peace and end the war. War begins with the use of military force and ends with the signing of a diplomatic document called a peace treaty or agreement. The same document marks the beginning of peace. The settlement of conflict through the introduction of peacekeeping actions is a long-term process, starting with peace enforcement, peacekeeping, and ending with peacebuilding.

War is the highest form of conflict, the manifestation of its greatest severity and the highest level of development of the conflict itself, which is characterized by the use of 
armed violence or armed struggle (Brecher, Harvey, 1998: 16). War is the most advanced form of conflict. The main feature of war as a form of conflict, unlike other forms of its manifestation and course, is its socio-political content. War is a special state of society and international relations. In society, such a special state is characterized as a state of war, when a state of war is declared in the state, one of the signs of which is the introduction of martial law. In international relations, such a state is the declaration war on another state through the implementation of a certain diplomatic act.

The state of war in the state is a very complex socio-political phenomenon, subject to the laws of wartime. It requires a huge strain on the material and spiritual forces of society and state. In war, not only the interests of the social actors who lead it are clearly manifested, but also the attitude of various social forces in society to it. Here, the warring parties are the subjects of great social significance: society, the state, the bloc of states, and sometimes broad social strata. Therefore, huge material resources are involved in the war: military equipment, human masses, and a variety of forms and means of warfare are used. War inspects carefully the strength and viability of the socio-political system (Perepelytsia, 2003: 63). The course and end of the war depend on the level of development of the productive forces, science and technology, the economic system of the belligerents, the socio-political system, the ideology and morale of the people and the army, as well as the combat power of the armed groups.

As a special state of international relations war is regulated by international law (Arcibasov, Egorov, 1989: 74-79). In this international context, war, unlike the general characteristics of conflict, is a foreign policy phenomenon. The essence of war lies in its political nature, which is subordinated to the means of armed violence, that is, military force, as the main resource of war (Brecher, Harvey, 1998: 14-15).

That is why generally accepted definition of "war" is formulated as a "socio-political phenomenon," which is an extreme form of resolving socio-political, economic, ideological, as well as national, religious, territorial and other contradictions between states, peoples, nations, classes and social groups by means of military violence (Politicha enciklopedia, 2011: 105).

The classics of Marxism also pointed out the special importance of political evaluation of the war, considering each war as "a continuation of the data policy, interested states and the various classes within them" (Markcictcko-leninckoe uchenie, 1984: 23-24). It should be noted that such the narrowing of political evaluation solely by class interests significantly impoverishes it. After all, politics is formed not only by classes, but also by other influential social forces and sectors of society. However, the evaluation of the war as the highest form of military-political conflict is also methodically correct from the point of view of the interests of those political organizations, political and social forces that form and implement policy. Since there are several influential forces in society whose interests have a diverse orientation, the political evaluation of the war will be ambiguous. It is expressed in agreement or disagreement with the military-political course pursued by the leadership of the state. Political evaluation also includes an analysis of the international and domestic political situation, and the degree of implementation of political goals during the war.

The non-recognition of the political essence of war as a state of society or a state of international relations is a certain epistemological problem that has been debated for 
more than a century. The formula for the essence of war, as we know, was most aptly discovered by Carl von Clausewitz, who wrote in his book "On War" that "war is nothing but the continuation of political relations with the intervention of other (violent Author) means" (Clausewitz, 1937: 374). "Consequently, war can never be considered separately from political relations, and if this happens anywhere, then the common threads are torn apart in such a way and something meaningless and purposeless is obtained" (Ibid.). The criticisms of this formula are focused on the fact that war can be aimed not at achieving political goals, but at the ratio of politics and violence in war.

The first decisive attack on the Clausewitz formula was made by Erich Ludendorff for attaching too much importance to politics at a time when it should be completely subordinated to strategy. At the same time, Ludendorff referred to Clausewitz's quote: "The political dimension is the purpose of war, war is only a mean, you can never think by means without a purpose." From Ludendorff's point of view: "War is the highest expression of the "nation's will to live," and therefore politics must be subordinated to the interests of war" (Beeil, 2014: 301).

This scientific discussion was especially active during the period of detente of the international situation in the 80 's, when it was believed that nuclear warfare could not be a policy, since in it (the use of weapons of mass destruction) becomes so destructive that no political purpose can justify it (Miller,1999: 71; Maknamara, 1988). A new wave of discussion is currently linked to the fact that violence has lost its mass use in politics, while its forms and means have changed. Hence, according to Joseph Nye's definition, they began to talk about hard, soft, normative, structural power and other types of it. Means of violence in the war were modified, so the concept of "hybrid warfare," "proxy war" and so on were introduced. In turn, such a variety of means of warfare posed a new problem of defining the boundaries of war and peace, the criteria by which it is possible to separate peace from war, and war from peace.

\section{BLURRING OF THE LINES OF WAR AND PEACE AS A TREND OF A MULTIPOLAR WORLD IN THE XXI CENTURY}

Until the second half of the XX century, the signing of a peace treaty after hostilities on the terms of the winner was considered to be such a criterion for distinguishing war and peace. In the second half of the XX century, with the advent of nuclear weapons and the formation of the bipolar system, the situation changed radically. The emergence of a nuclear warfare could end not in peace, but in a global catastrophe. Under the influence of these factors, in the conditions of confrontation between the two geopolitical poles, the peace began to be called the "Cold War" and the war the "Cold Peace."

After the end of the "Cold War," when the threat of a global nuclear warfare was eliminated and the ideological confrontation between two political systems ceased due to the disappearance of the Soviet Union and the socialist camp, the problem of defining criteria for distinguishing between war and peace arose again.

According to these postulates of neorealism, the measure of the dominance of war or peace is the category of "power." War is a struggle for power, with the use of force, 
and "peace" is the relationship between states without the use of force. The border between war and peace: the absence/presence of armed struggle with the use of military force.

The neoliberal approach, as has already been explained, denies this thesis and argues that "power" as a category structurally includes not only "hard" but also "soft power." The latter is determined by economic, energy, social, humanitarian, ideologi$\mathrm{cal}$, technological, financial and other factors. These factors, in the context of interdependence, significantly limit the appearance of wars in international relations and contribute to the strengthening of peace and cooperation. Thus, according to these postulates, war as well as peace has many components of a non-military nature, therefore the border between peace and war is blurred. This blurring of their borders is reflected in such concepts as "hybrid peace" and "hybrid warfare."

Obviously, this blurring is significantly enhanced by the global trends that have already become inherent in the XXI century. The main trends that cause the emergence of hybrid warfare and hybrid peace are, particularly, those geopolitical shifts associated with the creation of a multipolar system of international relations and the inter-civilizational structuring of the new world order. In this context, there are imbalances between key players that can be easily overcome by methods of conducting hybrid warfares. After all, in a hybrid warfare, the balance of power loses its value due to the transfer of armed confrontation from the battlefield to the information, social and cognitive spheres. Moreover, if the social and information spheres are associated with a certain physical infrastructure, then the cognitive sphere is the least material because it exists in the human mind. As a result, such wars, according to Dr. Davis Alberts, consist of three main types of actions. Firstly, the improvement of traditional combat. Secondly, the evolution of what has been called non-traditional missions, that is, a fairly diverse set of actions, including humanitarian aid, special operations and low-intensity conflicts, peacekeeping operations and actions aimed at preventing the proliferation of weapons. And thirdly, the birth of a unique form of war for the information age.

The tactics and strategy of actions of the Russian side in the Russian-Ukrainian war on Donbas is subordinated to the tasks of the military-political level with the use of the "Anaconda" method for the complete depletion of Ukraine and its transformation into a failed-state, which will allow to extend Russian rule to other regions of the country following the example of the hybrid model, introduced in Donbas. Proceeding from the above-mentioned military-political goals, the tactics of the Russian troops' actions are intended to wage a long-term low-intensity conflict aimed at the complete exhaustion of Ukraine and its capitulation in the end. In this format of warfare, the main tactical tasks of Russian troops are: inflicting maximum losses on Ukrainian troops in manpower and equipment; conducting constant "disturbing" attacks with the aim of complete demoralization of the Ukrainian military and loss of their combat capability; systematic destruction of bases and other elements of Ukrainian defensive positions to their complete inability to restrain the offensive actions of Russian troops of the tactical level; minimization of own losses among Russian personnel; achieving the maximum quantitative, technical and qualitative advantage in the level of combat capability, coherence and combat stability over the Ukrainian forces. 
The escalation of hostilities during August 2014-February 2015 envisaged not only inflicting a military defeat on Ukraine and the destruction of Ukrainian troops, industrial and social infrastructure, but also creating a situation of chaos in the theater of military operations as well as in the system of military and public administration in Ukraine. Thus, a hybrid war, unlike conventional war, does not provide for the total physical destruction of cities and villages, an industrial base and the military-economic potential of a country-victim of an aggression. In this case, total destruction is replaced by the creation of complete chaos: chaos in Ukrainian society, primarily in the Donbas, in the war zone, and in the international environment.

Such chaos had to give rise to international instability, which would lead the leaders of the West into a state of despair. After that, a diplomatic attack is launched on Kyiv and the West, which is intended to force them to accept Moscow's conditions and fix them in the Minsk and Normandy formats or bilateral separate agreements. Further, Russia acts as a guarantor-peacemaker, Russian troops in Donbas put on blue helmets and thus legalize their presence in Donbas "as a guarantor of the Minsk agreements and the security and independence of the DPR and LPR."

Thus, in the international legal field and the international community, through the Minsk Agreements, Russia secured for itself the status of an "observer," "mediator" and "peacemaker" - the guarantor of the rights and freedoms of the Russian and Russian-speaking population of Donbas, and not a "belligerent" or "aggressor," avoiding responsibility for the committed aggression, which is classified as an international crime.

An important role in the active phase of the hybrid war was given to large-scale information operations, the main tasks of which were to convince the Ukrainian military, Ukrainian society and the international community that combat operations are conducted by units of the 1st and 2nd Army Corps of DPR and LPR. All Russian news agencies, mass media, TV channels and the Internet were involved. No less important tasks of the information offensive were to demoralize units of the Armed Forces of Ukraine, encourage them to desert, surrender, leave their positions. Among the methods of such an information war is the demonstration of atrocities and cruelty of the Ukrainian military against the local population. The Russian special forces, disguised as the Ukrainian National Guard, were supposed to sabotage on the territory of the DPR and LPR, with wide coverage in foreign media. At the same time, there was intensified anti-Ukrainian and anti-American propaganda in the international media in order to introducing a split in American-European and American-Ukrainian relations.

To provide information support for the military offensive operation, as early as March 2014, Russian information troops launched a new wave of powerful information attacks against Ukraine in order to initiate provocations and destabilize the situation, which would lead to a state of chaos in Ukraine, what would greatly facilitate a new Russian military invasion of Ukrainian territory. At the same time, Russian propaganda voiced political demands to the Ukrainian government, which Russia always demanded as an ultimatum and which were subsequently set forth in the Minsk-1 and Minsk-2 agreements. These are: relinquishing the Crimean Peninsula, the legalization of militants following the election results, which will mean the consolidation of Russian power in the separatist-controlled territories, the de facto federalization of the 
country and the renunciation of the Association Agreement with the EU (Levus, 2018). Thus, the new informational offensive of Russia had already been using the advantages of the Minsk-2 for Russia, regarding the change the political structure of Ukraine, and the very terms of the truce.

On the other hand, hybrid warfare involves a broad combination of diverse types of actors, to which you can not apply your superiority in military potential. National states or associations of national states are not the only possible players in such conflicts. Non-state actors (including political, ethnic and religious groups, organized crime, international and transnational organizations, and even individuals equipped with information technology) are able to organize information attacks and build information strategies to achieve the desired goals (Savin, 2011). However, the problem here lay in the considerable complexity of determining the parameters of hybrid warfare, one of the main features of which is the blurring of these parameters. The beginning and end of the hybrid warfare are also blurred, since it has no clear signs of its beginning, the policy of transition from a state of peace to a state of war. This divide between peace and war is being blurred.

Hybrid warfare as a new form of network or network-centric warfare can combine almost all forms of asymmetric conflicts, from terrorism or military occupation to classic types of warfare (Raine, 2019). Hybrid warfare itself is an advanced asymmetric conflict. Such asymmetric tools have proven to be most vulnerable to the United States and Europe. "These include the use of special-operations forces and internal opposition to create a permanently operating front through the entire territory of the enemy state, as well as informational actions, devices, and means that are constantly being perfected" (Gerasimov, 2013).

For example, Russian and foreign experts consider the introduction of special operations forces in the Russian-Ukrainian war during the seizure of Crimea and Donbas as a model for conducting military operations without losses. "The speed and suddenness of the green men," Norwegian researcher T. Bukwall says, "made it possible to seize the Crimean parliament and Ukrainian military's headquarters in Crimea in a short time. The coordinated actions of the military personnel of the special operations forces, using unmarked uniforms to seize the buildings of state authorities and other strategic objects, according to the estimates of Western experts, can be considered classic" (Bukkvoll, 2016: 28).

The participation of the Special Operations Forces in Donbas is different from the Crimean events. According to Western experts, additional information may indicate that the GRU special forces (the main intelligence department of the Russian Armed Forces) may have appeared in the region in early March 2014. In particular, there were about 150 GRU instructors in the Slovyansk region. In addition, it can be assumed that it was the Russians special forces who initiated the protests and seizure of administrative buildings in the towns of Donbas and did not allow local residents to exchange their surrender for money. According to experts, during July-August 2014, at least 3-4 special forces battalions, 250-300 soldiers each, were deployed in the region. A systematic rotation was carried out among the personnel, and the GRU servicemen themselves performed tasks in groups of 10-12 people (Hybrid war: in verbo et in praxi, 2017: 84$)$. 
Such covert actions of the Russian special forces only intensified the blurring of the state of war, which made it much more difficult for the Ukrainian leadership to make adequate decisions, which were ultimately never made. The difficulty of identifying Russian special forces as enemy troops and recognizing Russia as a belligerent led the Ukrainian leadership to call such actions terrorist and launched an anti-terrorist operation (ATO) instead of repelling Russian military aggression, recognizing it as an internal conflict.

The inadequate identification of the military operations of the Russian special forces by the Ukrainian authorities gave Putin reason to assert that "they are not there." Even after 7 years of war, international organizations and Western partners demand from Ukraine the confirmation presence of the Russian troops in the occupied territories of Donbas and their participation in hostilities against the Ukrainian Armed Forces. All this makes it possible for Russia to avoid an adequate response from Ukraine and the West, when it is difficult to identify military aggression under the condition of blurred boundaries between peace and a state of war (Temnycky, 2020). Thus, the blurring between the state of war and peace is achieved through the introduction of such principles of warfare as:

- the growing role of non-military means in achieving political and strategic goals, which in some cases have significantly exceeded the effectiveness of weapons;

- shifting the confrontation towards political, economic, informational, humanitarian and other non-military measures implemented with the use of the protest potential of the population;

- the hidden nature of military measures, including informational confrontation, cyber-attacks and actions of special forces;

- the transition to the open use of military force (often under the guise of peacekeeping activity and crisis management) already in its final stages, mainly to achieve ultimate success.

The last principle points to the specifics of the use of military means in a hybrid war, when they are used at the final stage of the war, or in case when informational and other non-military means do not lead to the desired effect. In this case, the military force performs the function of escalation of threat, which should make the victim more compliant. At the lower level of such an escalation, as a rule, irregular military formations (units of mercenaries, militants or private armies) are engaged, which use the target vulnerabilities of the enemy, avoiding direct clashes with regular formations of the Armed Forces of Ukraine. After that, regular units of the Russian Armed Forces are used at a medium level of escalation. At the highest level of escalation of threat, Russia threatens to use tactical nuclear weapons. This function of intimidation of the tactical nuclear weapons use, which Putin threatens West with, is carried out in the event the latter turns to an adequate military response to the potential military aggression of Russia. It is no coincidence that the main issue at the first meeting of Joe Biden with Putin in Geneva on June 16, 2021 was an attempt to agree on preventing the development of a hybrid war into a nuclear one.

An example of such an escalation of threat was the build-up of Russian troops to 120,000 people on the Russian border in April 2021, which expedited the aforementioned meeting between Joe Biden and Putin, as well as led to the intention of Merkel 
and E. Macron to invite Putin to the EU summit. So far, the West's concessions to Russia may include: refusal to provide Ukraine with a NATO Membership Action Plan, Germany's refusal to sell weapons to Ukraine, refusal to send two American missile destroyers into the Black Sea for political and diplomatic support of Ukraine, and other concessions towards Russia. Thus, the buildup of Russian troops on the RussianUkrainian border turned out to be means of pressure and certain sowing of fear in the political circles of Ukraine and the West towards Russia, against which it is not able to act effectively.

The combination of the use of these non-military means with the military gives Russia the opportunity to present its war against the West as a peaceful relationship. Thus, due to the uncertainty of a clear watershed between hybrid warfare and hybrid peace, "hybrid peace" cannot be defined as a state of absence of war, since it contains certain elements of war.

This is a peace in constant danger and the constant threat of weapons and violence. At the same time, "hybrid warfare" includes active military operations, truce, negotiations, and peacekeeping activities at different stages of the conflict escalation. As Marcel H. Van Herpen notes "In this new form of war, the dividing line between peace and war has also become blurred. There is no declaration of war, military actions follow immediately after the 'peace negotiations' and 'final truce,' during which the hybrid warfare, still continues through with less intensity" (Herpen 2014: 34). This is confirmed with incredible accuracy by the course of hostilities in the Donbas during 2014-2015 and the so-called "truce" in accordance with the Minsk Agreements.

As for the truce, Russian troops in Donbas, unlike Ukrainian units, are conducting systematic hostilities despite their ban by the Minsk agreements. The enemy is actively using the ceasefire introduced by the Minsk agreements to increase the combat training of the mercenary strike units, replenish them with qualified personnel and inflict systematic losses on the Ukrainian armed forces. Accordingly, from the moment the Minsk Protocol was introduced until August 2016, during the period of the so-called "truce," according to summarized data, Ukraine lost 1,934 dead and 5,629 wounded soldiers. Thus, the hybrid peace cost Ukraine 7563 servicemen for more than two years, while during the active hostilities the losses amounted to about 4,000 soldiers killed and wounded. (Perepelytsia, 2017: 715).

On the other hand, the aggressor state in this way can deny the very fact of war, which is exactly what Russia does in this war, as well as Ukraine, but as a victim of aggression. Thus, Russia avoids international responsibility for violating the peace and territorial integrity of Ukraine, and Ukraine cannot use the force of international law against Russia as an aggressor. In this situation, the international community is disoriented, indifferent and passive in countering the aggressor state. This, by the way, explains to some extent the passive reaction of the leading states USA, Germany, UK, China, as well as such organizations as the EU and NATO to Russia's unleashed hybrid war against Ukraine.

Hybrid peace as well as hybrid warfare is a continuation of the same aggressive policy, with the same military and political goals as in hybrid warfare, only with the use of mostly non-military means, the main of which are informational and psychological influence and sabotage operations, and also the introduction of a conflict settle- 
ment process such as the Minsk one, or a negotiation process within the "Normandy format" on Donbas.

The ultimate goal of Russia in the implementation of the Minsk agreements is the transformation of Ukraine into a confederate state and the elimination of its state sovereignty through the legalization of the occupied territories through fake elections in these territories under Russian control and the presence of the OSCE. At the same time, an essential prerequisite for such a peace is the presence of Russian troops and their control over these territories, as it was in Crimea in the spring of 2014. And yet, the main means of achieving military-political goals in the state of a hybrid peace is not diplomatic, but informational ones. That is why such a hybrid peace is often equated with information warfare.

The main task of the aggressor in a state of hybrid peace is not to seize territories as during the war, but to impose his own picture of the world and his own system of values on the population of the country before the occupation of its territory. A hybrid peace must ensure a change in the mental space of the victim country before the war. Thus, by solving this problem of hybrid peace, the aggressor secures victory in the hybrid war.

This was the case in Ukraine before the beginning of war in 2014, when Russia occupied the Ukrainian information space and conducted anti-Ukrainian propaganda from these central and regional TV channels through the Ukrainian media (Zarembo, Solodkiy, 2021). This was especially noticeable in the Crimea and Donbas, where Ukrainian TV programs were not practically broadcasted. The Ukrainian press was almost never sold in these regions. Ukrainian schools were closed. Therefore, everything Ukrainian, even the language, were practically forced out of these regions. Pro-Russian parties, led by the ruling Party of Regions, conducted powerful anti-Ukrainian propaganda. Thus, the hybrid peace opens wide opportunities for the use of informational influence for the destruction of the enemy's combat potential, which greatly facilitates the implementation of combat missions during the military phase of the operation.

Such informational and psychological influence is based on narratives based on postmodernism and constructivism. They are aimed primarily at undermining the mass consciousness and creating chaos in the country - the victim of aggression. Constructivism for this purpose proved to be a convenient technology for the formation of such narratives as "gathering Russian lands," "Holy Rus," "Russians and Ukrainians are one people," "Americans organized a Nazi coup in Kyiv" and others. The main feature of such constructivist theories is anti-Americanism, the projection of own behavior on the enemy, when Russia attributes its own actions to the United States and Ukraine. For example, when Russia shifts responsibility for its aggressive actions to Ukraine, the United States and their allies. For example, "Ukraine and the United States launched a hybrid war against Russia," or "Ukraine attacked Donbas to wipe out the Russian-speaking population there." Having adopted the postmodernist postulate of the relativity of truth, Russian propaganda questions any facts. Instead, the place of truth is replaced by the subjective truth that everyone has. "Recognition of many selfsufficient debates, which are equated with each other in the status of truth, leads to the dissolution of truth as such, its content replaces the myth" (Hybrid war: in verbo et in praxi, 2017: 130). 
The Russian model of actions against Ukraine in a state of a hybrid peace was studied in detail by the military analyst Philip Karber, the implementation of which he divides into three stages: destabilization of Ukraine through fanning an internal conflict; attempts to destroy the Ukrainian state due to the catastrophic destruction of the economy and infrastructure; replacement of local authorities with their own supporters of "invitation of saviors" (Karber, 2015). Thus, both the hybrid peace and the hybrid war waged by Russia are aimed at inspiring internal conflicts and destructive processes, which lead to chaotization of the internal environment in the country-victim of the aggressor.

Of course, such a methodological basis of modernism is present in Russia's hybrid war against the West, which can also be represented as a hybrid peace. As the famous Russian political scientist Lilia Shevtsova notes, "Postmodernism, with its eclectic relativism, double standards, blurred lines between legal and illegal, truth and falsehood, peace and war, principles and pragmatism, is a perfect environment for a system like Russian one to prosper. The policy of the postmodern world allowed Russia to use a triadic model: to be with the West (cooperating with it when it is profitable), within the West (through personal integration of the Russian rentier class into Western society) and against the West (to isolate Russian society from Western influence). Putin is more postmodern than all Western leaders - including Schroeder, Chirac and Sarkozy, prominent representatives of political relativism. If Jürgen Habermas wrote a continuation of his famous work 'Modernism and Postmodernism,' he would probably call Vladimir Putin the embodiment of this trend" (Shevtsova, 2017).

In contrast to actions against Ukraine, in the context of the global confrontation with the West during the hybrid peace, Russia is concentrating its efforts on the following priorities: investing in key sectors of European economies; the use of Russian investment, trade and capital for bribes and increasing influence on the economic and political elite of Western countries; bribery of Western media representatives and support of anti-integration sentiments in pro-Russian political parties; sale of weapons and military equipment to influence military decision-making in foreign countries; large-scale penetration of intelligence into European organizations; establishing links between Russian organized crime and local criminal elements in the West; establishing contacts among religious institutions that exploit unresolved ethnic conflicts and launch campaigns against "minority rights;" significant support for Russian information abroad; massive coordination of cyberattacks on selected targets (Blank, 2015).

Seven years of Russia's hybrid war against Ukraine and the West have shown that it can cause a reverse effect on the international environment. First, by leveling the imbalance of power, hybrid warfare reverses the trends of the struggle for spheres of influence in the world, when its epicenter again shifts from the regional to the global level, which clearly identified new contenders for global dominance such as Russia and China. It is no coincidence that Joe Biden's new presidential administration, in an effort to maintain US global leadership in the World and prevent the emergence of new contenders, has clearly identified these countries as its main rivals. But if China seeks to establish symmetrical partnerships with the United States primarily in the economic sphere, Russia, being in a status of striking asymmetry with the United States, has 
chosen hybrid warfare as the most accessible and effective form of leveling and overcoming such asymmetry in the fight against Western dominance.

Second, the hybrid war enabled Russia to compensate for the lack of economic and military capabilities by non-military means, given their growing role.

Third, in the foreign policy dimension, Russia's hybrid war against the West, as well as the West's efforts to maintain a hybrid peace with Russia, reinforces the repressive nature of authoritarian regimes such as Belarus, Syria, Venezuela and Russia itself, or changes in democratic regimes such as Turkey towards the authoritarian tendencies.

Fourth, in the political dimension, under the influence of these trends, the geopolitical axis Moscow-Berlin-Paris is emerging, which threatens the integrity of the EU and Euro-Atlantic solidarity. Thus, the blurring of the boundaries between war and peace opens wide opportunities for substituting the real causes of conflict with declarative, substituting the subjectivity of the parties to the conflict and traditional indicators of the beginning and end of war and peace, substituting the values and goals of war and peace, which constitutes the content of hybrid war and peace.

Fifth, in the international security sphere, the process leads to the loss of the effectiveness of international law and the capacity of the existing structures of international security; they do not have adequate capabilities to counteract hybrid warfare, since they are built on the prevention of conventional and nuclear war.

\section{PRACTICAL CONSEQUENCES OF THE ABSENCE OF BOUNDARIES BETWEEN WAR AND PEACE IN THE RUSSIAN-UKRAINIAN CONFLICT}

The unresolved dilemma of war and peace in a purely scientific context had its very specific consequences in the real conditions of war. The tendency to blur the boundaries between war and peace led to the substitution of concepts, when war came to be called peace and peace a war. The consequence of such sophistic manipulation was the erosion of responsibility for the preservation of peace and defense of the country, as well as for the state of international security.

Such a substitution of concepts led to the fact that the main goals set by the state's leadership were not to achieve victory, organize the defense of state or defeat the aggressor, but to "resolve the conflict." At the same time, sometimes the term "conflict resolution" was used as a concept identical to the term "outbreak of war" (that is, aggression).

This conceptual confusion has led to disorientation of both Ukrainian society and the international community. The Ukrainian leadership at the official and international level has not dared to name the war waged by Russia against Ukraine "the RussianUkrainian war," but named it a conflict in the form of an "Anti-terrorist operation" (ATO), or "United forces operation" (UFO), limiting its scope to the occupied Russian troops in the territory of Donbas. Such sophistry allowed the highest military and political leadership of Ukraine to remove from itself the task of organizing the defense of state, imposing martial law, achieving victory over the enemy or defeating it, and such sophistry allowed the Ukrainian society to avoid a state of war. The slogan "end 
the war and achieve peace," which Ukraine does not officially recognize by resolving the conflict in the Donbas, is eclectic, since it does not answer the question with what result we should end this war.

Thus, the outlined analysis of approaches to defining the features of hybrid warfare makes it possible not only to find out its general and specific essence as a type of conflict and a specific form of war, but also a hybrid peace. The main signs of hybridity of the peace are largely due to the hybrid nature of the warfare itself, when the time of the end of the war and the onset of peace does not have a clear fixation of the moment of their beginning. There is no clear border between them, as well as the border between the state of peace and wartime. In this case, the peculiarity of the hybrid peace introduced by Ukraine is manifested in the fact that war and military operations are conducted in peacetime, where the government and society are guided by legislative acts and norms that regulate their activities and relationships in peacetime.

At the international level, this substitution of concepts allowed Russia to interpret the Russian-Ukrainian war as a "civil war" in Ukraine, and the international community to consider this war as an "internal conflict" in Ukraine between the central government and the Donbas region as a "Ukrainian crisis." Both positions Russia not as an aggressor who started the war and not as a belligerent party, but as a "mediator," which already removes from Russia and its leadership criminal and international responsibility for committing this war.

The settlement conflict on the Donbas does not provide for the return of the Crimea occupied by Russia to Ukraine, since Crimea is not included in the plot "the settlement conflict on the Donbas." It is present in the context of the Russian-Ukrainian war, which in reality will not end even if the conflict on the Donbas is resolved, which is unlikely in the conditions of war, since the Donbas in the categories of war is only one of its military theatres, one of the stages of this war.

The Ukrainian leadership, as well as the Ukrainian society, want peace on the Donbas and the return of its occupied territory to Ukraine by settlement this conflict. However, the main result of settlement the conflict is not the achievement of peace, but the achievement of a compromise that removes the main contradiction between the warring parties. That's not necessarily that as a result of such a compromise, Ukraine will return Donbass under its control and reach peace with Russia. The price of compromise is sometimes much higher than the price of victory and can become a defeat, being equivalent to the price of surrender. When settlement a conflict, victory is not on the agenda. The main prize here is to reach a consensus on the basis of which a stable peace is then built. The main goal of any peacekeeping activity is to establish peace between the warring parties, not to achieve the victory of one of them or the return of territories or the restoration of control over the border. This means that the introduction of a peacekeeping operation in the Donbas will not bring the expectations that the government encourages the Ukrainian society.

The settlement of the conflict on the Donbas can bring peace, but not the one that Ukrainian society expects. For such a peace we may have to pay too much, and this peace will not necessarily be fair, since the main goal in settlement the conflict is to establish peace, whether this peace is fair or not. Based on this, we can get not stable and lasting peace. Therefore, "peace at any cost" is considered unfair. 
The hypothesis of the study is confirmed by the fact that the essential feature of the dilemma of war and peace of the XXI century in comparison with the nuclear age is the blurring of the line between peace and war and the emergence of such phenomena as hybrid peace and hybrid war. On the example of the Russian-Ukrainian war that broke out in Donbas on the territory of Ukraine, it is proved that such a combination of war and peace creates chaos and anarchy in international relations, when such a war can be simultaneously classified as "Ukrainian crisis," "internal conflict," local war, regional war, global conflict, and qualified as a hybrid peace in all these dimensions.

The analysis showed that in such a situation, war and peace lose their parameters and manifestations. The beginning and the end of the hybrid war are also blurred, because it has no clear signs of its beginning, the transition of politics from a state of peace to a state of war. This divide between peace and war is blurring. Moreover, these states can pass into each other. That is why a "hybrid peace" cannot be defined as a state of absence of war, because it contains certain elements of war. This is a world of constant danger and the constant threat of the use of weapons and violence. At the same time, "hybrid war" includes active hostilities, armistices, negotiations, and peacekeeping operations at various stages of its escalation. At the same time, "hybrid war" includes both active hostilities and armistices, and negotiations, and peacekeeping measures at various stages of its escalation. In this situation, the international community is disoriented, indifferent and passive in counteracting the aggressor state.

Such a complex situation requires a conceptual rethinking and a new reading of the dilemma of war and peace, which are becoming hybrid. Therefore, understanding the new characteristics of these hybrid forms of war and peace is a very important and necessary task.

\section{REFERENCES}

Ackermann A. (1999), Making peace prevail: preventing violent conflict in Macedonia, Amsterdam.

Banasik M., Parafianowicz R. (2015), Teoria i praktyka działań hybrydowych, „Zeszyty Naukowe AON", No. 2(99): 5-25, http://yadda.icm.edu.pl/baztech/element/Banasik_ZN_ AON_2 2015.

Blank St. (2015), Russia, Hybrid War and the evolution of Europe. Second Line of Defense, 14.02.2015, http://www.sldinfo.com/russia-hybrid- war-and-the-evolution-of-europe/.

Brecher M., Harvey F. P. (1998), Conflict, Crisis and War: Cumulation, Criticism, Rejoinder, in: Conflict in World Politics: advances in the Study of Crisis, War and Peace, (eds.) F. P. Harvey, B. D. Mor, New York.

Boulden J. (2001), Peace Enforcement: The United Nations Experience in Congo, Somalia, and Bosnia, Westport, Connecticut London, London.

Bukkvoll Tor. (2016), Russian Special Operations Forces in the war in Ukraine - Crimea and Donbas, in: The US Army War College Quarterly, "Parameters" 46, No. 2, https://press.armywarcollege.edu/parameters/vol46/iss $2 / 4$. 
Conflict in World Politics: advances in the Study of Crisis, War and Peace (1998), (eds.) F. P. Harvey, B. D. Mor, New York.

Copeland D. C. (2001), Economic Interdependence and War: Theory of Trade Expectations, in: Theories of war and peace: an international security reader, (eds.) M. E. Brown, R. Owen, Cote Jr. ... (et al.), Cambridge, Massachusetts-London.

Dickinson P. (2021), All roads lead to Ukraine in Putin `s global war, Atlantic Caunsil, Jan 5, https:// www.atlanticcouncil.org/blogs/ukrainealert/all-roads-lead-to-ukraine-in-putins-global-hybrid-war/.

Dodonov R. (2015), Crisis, War or Conflict - how Correctly to Call Events in the East of Ukraine? Skhid, No. 2 (134).

Hopmann T. (2000), The Organization for Security and Cooperation in Europe: Its Contribution to Conflict Prevention and Resolution, in: International conflict resolution after cold war, (eds.) P. C. Stern, D. Druckman, Washington DC.

Herman M. (1996), Intelligence Power in Peace and War, London.

Неrрен M. X. Van (2014), Vojni Putina. Chechny. Gruzia. Ukraine: nezasvoeni uroki minulogo, Xarкiv.

Homer-Dixon T. F. (2001), Environmental Scarcities and Violent Conflict: Evidence from Cases, in: Theories of war and peace: an international security reader, (eds.) M. E. Brown, R. Owen, Cote Jr. ... (et al.), Cambridge Massachusetts-London.

Holsti K. J. (1998), Peace and War: Armed Conflicts and International Order 1648-1989, New York. International conflict resolution after cold war (2000), (eds.) P. C. Stern, D. Druckman, Washington DC.

Jacobsen C. G. (2000), Searching for Peace: The Road to Transcend, (eds.) J. Galtung, C. G. Jacobsen, London-Sterling-Virginia.

Karber Dr. Phillip A. (2015), Russia's Hybrid War Campaign, Implications for Ukraine \& Beyond, CSIS, 1 March, Washington, http://fortunascorner.com/wp-content/uploads/2015/03/ hybridwarfarebrief.

Leech J. (2002), Asymmetric Conflict: war without death, London.

Lewis W. H., Marks E. (1998), Search for Partners: regional organizations and peace operations, "McNair Paper", No. 58.

Long W. J., Brecke P. (2003), War and Reconciliation: reason and emotion in conflict resolution, London.

Mearsheimer J. J. (2001), Back to the Future: instability in Europe after the Cold War, in: Theories of war and peace: an international security reader, (eds.) M. E. Brown, R. Owen, Cote Jr. ... (et al.), Cambridge, Massachusetts-London.

Miller D. (1998), The Cold War: a military history, New York.

Nations at War: a scientific study of international conflict (1998), (eds.) D. S. Geller, J. D. Singer, Cambridge, United Kingdom.

Nye J. S. (2004), Soft Power: The Means to Success in World Politics, "Public Affairs", 04.05.2004.

Owen J. M. (2001), How Liberalism Produces Democratic Peace, in: Theories of war and peace: an international security reader, (eds.) M. E. Brown, R. Owen, Cote Jr. ... (et al.), Cambridge, Massachusetts-London.

Paul T.V. (1994), Asymmetric Conflicts: war initiation by the weaker powers. New York - Melbourne.

Pfersch F. R., Rohloff C. (2000), National and International Conflicts, 1945-1995: new empirical and theoretical approaches, London. 
Raine J. (2019), War or peace? Understanding the grey zone. IISS, London, https://www.iiss.org/ blogs/analysis/2019/04/understanding-the-grey-zone.

Regan P. M. (2000), Civil War and Foreign: outside intervention in intrastate conflict, Michigan Press, 2000.

Roman Ł. (2017), O wojnie i pokoju - dylematy polemologiczne, Centrum Naukowo-Badawcze Ochrony Przeciwpożarowej im. Józefa Tuliszkowskiego - Państwowy Instytut Badawczy, http://yadda.icm.edu.pl/baztech/element/bwmeta1.element.baztech-7cf8aad3-9b5c-48d0-b3e6-811adaf7080e/c/BITP_Vol_45_Issue_1_2017_pp.80-86.pdf.

Rosa R. (2018), Problemy wojny w perspektywie filozoficznej, Repzytorium Uniwersytet Przyrodniczo-Humanistyczny w Siedlcach: 33-50, https://repozytorium.uph.edu.pl/bitstream/handle/11331/2078/Problemy\%20wojny\%20w\%20perspektywie.pdf?sequence=1.

Temnycky M. (2020), For Ukraine, endless Putin means endless hybrid war, in: Atlantic Counsil, Mon, Aug 3, 2020, https://www.atlanticcouncil.org/blogs/ukrainealert/for-ukraine-endless-putin-means-endless-hybrid-war/.

The History and Future of Warfare: selection from professional readings in military strategy published by the StraAtegic Studies institute of the U.S. Army War College (1999), (eds.) H. H. Almound, J. A. Burger, The Hague-London-Boston.

Theories of war and peace: an international security reader (2001), (eds.) M. E. Brown, R. Owen, Cote Jr. ... (et al.), Cambridge, Massachusetts-London.

Symonides J. (1983), Problemy pokoju i bezpieczeństwa międzynarodowego we wspótczesnym świecie, in: Wychowanie dla pokoju, (ed.) B. Suchodolski, Zakład Narodowy im. Ossolińskich, Wrocław.

Wiatr J. (1964), Socjologia wojska, Wydawnictwo MON, Warszawa.

Arcibasov I. N., Egorov C. A. (1989), Voorujenniy conflict: pravo, politika, diplomatia, Moskva.

Beeil L. G. (2014), Strategia nepriamich deystviy (perevod c angliyskogo), Moskva.

Bazaluk O. (2016), Theory of War and Peace. The Geofilosophy of Europe, MFKO Publishing, Kyiv.

Clausewitz K. (1937), O wojne, Moskva.

Dulebova I., Kovalskyi H., Dodonova V., Biletsky V. (2018), War and peace: ways to peace in war in the Eastern Ukraine, "Skhid", № 5(157): 59-65, https://doi.org/10.21847/17289343.2018.5(157).148638.

Gareev M. (2013), Predhustvie izmeneniya v haraktere woyni, in: Voenno-provishlenniy kurjer, No. 20 (488)-22 (490), 29 (497).

Gerasimov V. (2013), Cennost nauki v predvidenii, in: Voenno-provishlenniy kurjer, No. 8 (476).

Filosofckiy eyciklopedicheskiy slovar (1983), (eds.) L. F. Iliychov, P. N. Fedoceev, Mosкva.

Hybridna wojna: in verbo et in praxis (2017), (ed.) R. O. Dodonov, Vinnica.

Horbulin V. (2017), The World Hybrid War: Ukrainian Forefront: monograph abridged and translated from ukrainian, Kharkiv.

Levus A. (2015), Kreml gotovitcya $\kappa$ novoy "russkoy vecne" na Dombasse, Birgevoy lider, 03.03.2015, http://www.profi-forex.org/novosti-mira/novosti-sng/ukraine/entry1008247392. html.

Макnamara R. (1988), Putem oshibok k katastrofe, Moskva.

Markcictcko-leninckoe uchenie o wojne i armii (1984), (ed.) D. A. Volkogonov, Moskva.

Mejdunarodnoe pravo (1994), (eds.) U. M. Kolosov, V. I. Kusnecov, Moskva.

Mocov C. P. (2007), Wojna ili mir - vibor sa chelovechestvom, Kyiv. 
Parahonskiy B. O., Yavorska G. M. (2019), Ontologia wojni i miru, Kyiv.

Perepelytsia H. M. (2003), Genezis konflikiv na postkomunistichnomu prostory Evropi, Kyiv.

Perepelytsia H. M. (2017), Ukraine - Rossia: wojna v umovah spivisnuvannia, Kyiv.

Perepelytsia H. M. (2016), Rossiysko-ukrainskiy konflikt: hybridniy mir protiv hybrydnoy wojni, in: Sovnishnya politika Ukraine 2015: strategichni ocinki, prognozi ta prioryteti, (ed.) H. M. Perepelytsia, Kyiv.

Politicha enciklopedia (2011), (eds.) U. A. Levinec, U. I. Shapoval, Kyiv.

Savin L. V. (2011), Beskontaktnie i cetevie wojni. Vvedenie v koncepciy, Moskva.

Shevtsova L. (2017), Survival in The Trumpian World, "The American Interest", February 22, 2017, http://www.the-american-interest.com/2017/02/22/survival-in-the-trumpian-world/.

Solovyov A. V. (2002), Polemologia, in: Voennaya enziklopedia, Vol. 6, (ed.) C. B. Ivanov, Moskva. Woennay doktrina Rossiyckoy Federacii (2014), https://rg.ru/2014/12/30/doktrina-dok.html.

Woenna doktrina Ukraine (2015), Ukas Presidenta Ukraine № 555/2015, https://www.president.gov. ua/documents/5552015-19443 (16.01.2020).

Wojna i mir, abo ukrainci-polyaki: brati/vorogi, cucidi (2012), (ed.) L. Ivshina, Kyiv.

Zarembo K., Solodkiy S. (2021), The Evolution of Russian Hybrid Warfare: Ukraine, CEPA, January 29, https://cepa.org/the-evolution-of-russian-hybrid-warfare-ukraine/.

\begin{abstract}
In the presented article the author asks how the essence of the relationship between such states of international relations as war and peace has changed under the influence of the trends of the XXI century. A clear empirical example for such an analysis was the modern RussianUkrainian war, a manifestation of which we see on the Donbass. This war was largely the result and manifestation of these new trends in international relations at both the regional and global levels. First of all, these trends and their destructive consequences are typical for the security sphere. From so the dilemma of war and peace takes on a new dimension and becomes one of the most pressing problems of the theory of war and peace and the theory of international relations.

The purpose of this article is to understand how the essence of the relationship between such states of international relations as war and peace has changed under the influence of the 21 st century trends. In order to properly investigate this problem, was chosen as an object, a striking manifestation of which we see on the Donbass. Research questions relate to changing approaches to understanding the dilemma of war and peace and the nature of the relationship between these states of international relations under the influence of the 21 st century trends.

To address this research challenge, a systematic review of contemporary research on various aspects of war and peace has been carried out. The answers are based on a study of the criteria for determining the state of war and peace and the determinants that influence the dynamics of change in these states. The study used deductive methods, comparative, political and conflict analysis, as well as neo-realistic and neoliberal approaches to treating the dilemma of war and peace.

The article based on the assumption that the modern Russo-Ukrainian war became a consequence and manifestation of these new trends in international relations both at the regional and global levels. The conclusions drawn from this study require a conceptual rethinking and a new reading of the dilemma of war and peace, which are becoming hybrid. Therefore, understanding the new quality of these hybrid forms of war and peace is a very important and necessary task. To solve it, it is necessary to determine how the parameters of the relationship between
\end{abstract}


peace and war have changed. Empirical observations show that one of the new features of this relationship is the blurring of the boundaries of war and peace.

The objectives of the study are based on the discovery of a new content of the categories of war and peace and their interdependence due to the influence of 21 st century trends in the modern system of international relations. The results of the study are based on the analysis of modern research on various aspects of the war and peace, as well as empirical data on the course of the Russian-Ukrainian war.

This article provides an overview of current research on various aspects of war and peace, identifies the interrelationships, interdependencies, and boundaries between hybrid warfare and hybrid peace. The author tried to define the criteria for such a distinction between war and peace, based on the neoliberal and neorealist theory of international relations. The scientific novelty of this publication is that the author clarified the methodological reasons for the unresolved dilemma of war and peace in the current trends of the 21 st century. The article concludes with a forecast of the consequences of the unresolved dilemma of war and peace for national and international security. Recommendations are given for a possible solution to the problem of war and peace on Donbass.

The research presented in this article is an attempt to conceptually rethink and re-read the dilemmas of war and peace that are becoming hybrid. The article greatly expands the understanding of how the parameters of the relationship between peace and war have changed.

Key words: war, peace, conflict, dilemma, Donbas

\section{DYLEMAT WOJNY I POKOJU W TRENDACH XXI WIEKU (Przypadek rosyjski - ukraiński)}

\section{STRESZCZENIE}

W prezentowanym artykule autor pyta, w jaki sposób istota relacji między takimi państwami stosunków międzynarodowych, jak wojna i pokój, zmieniła się pod wpływem trendów XXI wieku. Wyraźnym empirycznym przykładem takiej analizy była współczesna wojna rosyjsko-ukraińska, której żywy przejaw obserwujemy w Donbasie. Ta wojna była w dużej mierze wynikiem i przejawem tych nowych trendów w stosunkach międzynarodowych zarówno na poziomie regionalnym, jak i globalnym. Przede wszystkim te trendy i ich destrukcyjne konsekwencje są typowe dla sfery bezpieczeństwa. Stąd dylemat wojny i pokoju nabiera nowego wymiaru i staje się jednym z najbardziej palących problemów teorii wojny i pokoju oraz teorii stosunków międzynarodowych.

Celem artykułu jest zrozumienie, jak istota relacji między takimi państwami stosunków międzynarodowych, jak wojna i pokój, zmieniła się pod wpływem trendów XXI wieku. Aby właściwie zbadać ten problem, wybrano obiekt, którego uderzającą manifestację widzimy na Donbasie. Pytania badawcze dotyczą zmieniającego się podejścia do rozumienia dylematu wojny i pokoju oraz natury relacji między tymi stanami stosunków międzynarodowych pod wpływem trendów XXI wieku.

Aby sprostać temu wyzwaniu badawczemu, przeprowadzono systematyczny przegląd współczesnych badań dotyczących różnych aspektów wojny i pokoju. Odpowiedzi opierają się na badaniu kryteriów określania stanu wojny i pokoju oraz uwarunkowań wpływających na dynamikę zmian w tych państwach. W badaniu wykorzystano metody dedukcyjne, analizę porównawczą, analizę polityczną i konfliktową, a także podejście neorealistyczne i neoliberalne do rozwiązywania dylematu wojny i pokoju. 
Artykuł opierał się na założeniu, że współczesna wojna rosyjsko-ukraińska stała się konsekwencją i manifestacją tych nowych trendów w stosunkach międzynarodowych zarówno na poziomie regionalnym, jak i globalnym. Wnioski wyciągnięte z tego badania wymagają przemyślenia konceptualnego i nowego odczytania dylematu wojny i pokoju, które stają się hybrydami. Dlatego zrozumienie nowej jakości tych hybrydowych form wojny i pokoju jest bardzo ważnym i koniecznym zadaniem. Aby go rozwiązać, konieczne jest ustalenie, jak zmieniły się parametry relacji między pokojem a wojną. Z obserwacji empirycznych wynika, że jedną z nowych cech tej relacji jest zacieranie się granic wojny i pokoju.

Cele badania opierają się na odkryciu nowej treści kategorii wojny i pokoju oraz ich współzależności w wyniku wpływu trendów XXI wieku na współczesny system stosunków międzynarodowych. Wyniki pracy opierają się na analizie współczesnych badań dotyczących różnych aspektów wojny i pokoju, a także danych empirycznych dotyczących przebiegu wojny rosyjsko-ukraińskiej. Ten artykuł zawiera przegląd aktualnych badań dotyczących różnych aspektów wojny i pokoju, identyfikuje współzależności i granice między wojną hybrydową a pokojem hybrydowym.

Autor próbował zdefiniować kryteria takiego rozróżnienia między wojną a pokojem w oparciu o neoliberalną i neorealistyczną teorię stosunków międzynarodowych. Nowością naukową tej publikacji jest wyjaśnienie przez autora metodologicznych przyczyn nierozwiązanego dylematu wojny i pokoju w obecnych trendach XXI wieku. Artykuł kończy się prognozą konsekwencji nierozwiązanego dylematu wojny i pokoju dla bezpieczeństwa narodowego i międzynarodowego. Podaje się zalecenia dotyczące możliwego rozwiązania problemu wojny i pokoju w Donbasie.

Badania przedstawione w tym artykule są próbą konceptualnego przemyślenia i ponownego odczytania dylematów wojny i pokoju, które stają się hybrydami. Artykuł znacznie poszerza wiedzę o tym, jak zmieniły się parametry relacji między pokojem a wojną.

Słowa kluczowe: wojna, pokój, konflikt, dylemat, Donbas 
